\title{
Diklat Kepemimpinan Pola Baru Dalam Perspektif Inovasi dan Pembelajaran Konstruktivistik
}

\author{
Lilin Budiati ${ }^{1}$
}

Diterima : 13 Juli 2015

Disetujui : 12 Agustus 2015

\begin{abstract}
The State Administration Body (Lembaga Administrasi Negara/LAN) enacted the new model of leadership education and training by year 2013 for replacing the old model which was assessed as ineffective. This model applied the contstructivistic paradigm that emphasizes on student centered and experience based learning approaches. Some problems were identified with respect to those matters are as follows: (1) What are the differences of the new and the old model?; (2) What is the strategic meaning of the new model leadership education and training?; (3) What are the obstacles of its implementation?. This study was a library research which used the secondary data and analysis was performed by comparing the new and the old model of leadership education and training. The result of study indicates three aspects of learning process as the following: (1) The new model applied "proyek perubahan" as an instrument for generating an "experience" which could formalize the student competence of leadership; (2) The new model of leadership and training creates the outcome oriented leader within the well reformed bureaucracy; (3) The main obstacle of its implementation are its complexity and incompatibility with the low level of competence of the trainer (widyaiswara) in performing this new model. Based on those conclusion, it could be recommended to the State Administration Body to perform a training of trainer for enhancing their capabilities and capacity.
\end{abstract}

Keywords: Leadership Education and Training, Constructivism, Innovation

\begin{abstract}
ABSTRAK
Badan Administrasi Negara (Lembaga Administrasi Negara / LAN) menetapkan model baru pendidikan kepemimpinan dan pelatihan tahun 2013 untuk menggantikan model lama yang dinilai tidak efektif. Model ini menerapkan paradigma konstruktivistik yang menekankan pada peserta didik dan pengalaman berdasarkan pendekatan pembelajaran. Beberapa masalah yang diidentifikasi sehubungan dengan hal tersebut adalah sebagai berikut: (1) Apa perbedaan dari baru dan model lama ?; (2) Apa arti strategis pendidikan kepemimpinan model baru dan pelatihan ?; (3) Apa kesulitan pelaksanaannya ?. Penelitian ini merupakan suatu studi kepustakaan yang menggunakan data sekunder dan analisis dilakukan dengan membandingkan model baru dan model lama pendidikan kepemimpinan dan pelatihan. Hasil penelitian menunjukkan tiga aspek proses belajar sebagai berikut: (1) Model baru diterapkan "Proyek perubahan" sebagai alat untuk menghasilkan sebuah "pengalaman" yang bisa membentuk kemampuan kepemimpinan siswa; (2) Model baru dari kepemimpinan dan pelatihan menciptakan hasil pemimpin yang berorientasi dalam birokrasi juga direformasi; (3) Kendala utama pelaksanaannya adalah kompleksitas dan ketidakcocokan dengan rendahnya tingkat kompetensi pelatih (Widyaiswara) dalam melakukan model baru ini. Berdasarkan kesimpulan tersebut, bisa direkomendasikan kepada Badan Administrasi Negara untuk melakukan pelatihan pelatih untuk meningkatkan kemampuan dan kapasitas mereka.
\end{abstract}

Kata kunci: Pendidikan dan Pelatihan Kepemimpinan, Konstruktivisme, Inovasi

${ }^{1}$ Widyaiswara Provinsi Jawa Tengah, Dosen Luar Biasa Magister Pembangunan Wilayah dan Kota, Universitas Diponegoro Kontak Penulis : lilinbudiati@yahoo.com 


\section{PENDAHULUAN}

Pada pertengahan tahun 2013, LAN RI menerapkan Diklat Pim Pola Baru menggantikan Diklat Pim Pola lama yang dianggap tidak efektif (Lilin Budiati, 2012). Model pembelajaran Diklat Pim ini merupakan perubahan dari paradigma pembelajaran behavioristik dan kognitivistik yang berbasis perilaku dan berorientasi pada guru (teacher centered learning) menjadi pembelajaran konstruktivistik yang berbasis pengalaman dan berorientasi pada peserta didik (student centered learning). Perubahan ini dapat dimaknai sebagai suatu inovasi yang mencakup dua perspektif yaitu: pertama, Inovasi kebijakan sektor publik yang bertujuan menciptakan pemimpin masa depan yang berintegritas dan berkarakter; dan kedua, inovasi metode pembelajaran yang menekankan pada aspek belajar secara langsung dari pengalaman peserta didik pada saat merancang dan mengerjakan proyek perubahan. Ketidakberhasilan Diklat Pim di masa lalu disebabkan karena Diklat Pim Pola Lama tidak menyentuh aspek-aspek pembentukan integritas dan karakter kepemimpinan yang justru merupakan salah satu faktor kunci keberhasilan reformasi birokrasi. Pembelajaran Diklat Pim Pola lama lebih menekankan pada aspek kognitif dibanding aspek perilaku kepeimpinan, sehingga perlu dilakukan inovasi pada kebijakan dan sekaligus metode pembelajaran yang terkonvergensikan dalam bentuk Dklat Pim Pola Baru. Self Mastery sebagai agenda pertama kurikulum Diklat Pim Pola Baru, menjadi prasyarat keberhasilan LAN RI beserta jajaran Badan Diklat di bawahnya untuk menciptakan pemimpin birokrasi masa depan guna mewujudkan reformasi birokrasi secara menyeluruh di semua tingkatan.

Setiap inovasi, termasuk Diklat Pim Pola Baru, akan selalu menimbulkan ketidakpastian terutama di tahap-tahap awal proses adopsi dan implementasinya. Hal itu disebabkan karena ketidaktahuan atau ketidakjelasan tentang makna, substansi, arah, tujuan dan terutama mengenai bagaimana cara mengaplikasikan inovasi tersebut. Akan terjadi perbedaan persepsi atau salah persepsi, inkonsistensi dan bahkan penyimpangan-penyimpangan dalam implementasi Diklat Pim Pola Baru adalah risiko yang tak terhindarkan dalam setiap perubahan. Salah satu wujud salah persepsi adalah bahwa Diklat Pim Pola Baru dimaknai secara simplistis sebagai pendekatan atau metode baru yang tidak memperbolehkan dipakainya beberapa alat bantu (tool) analisis seperti fishbone, pohon masalah, SWOT danForce Field Analysis (FFA) dalam pembelajaran karena sudah kedaluwarsa atau ketinggalan jaman. Proses berpikir dialektis (tesis - anti tesis - sintesis) direduksi atau disederhanakan oleh cara pandang bahwa "jika sudah ada metode atau tool yang baru berarti metode atau tool yang lama tidak boleh dipakai”. Cara pandang seperti ini jelas keliru dan menyesatkan.

Salah persepsi, perbedaan persepsi, inkonsistensi dan penyimpangan praktik pembelajaran merupakan masalah utama yang dihadapi oleh semua Badan Diklat Provinsi maupun Badan Diklat Kabupaten/Kota saat ini. Masalah-masalah tersebut timbul sebagai akibat "ketidakpasian" yang disebabkan oleh inovasi kebijakan dan pembelajaran Diklat Pim Pola Baru. Diperlukan suatu kajian riset kepustakaan (library research) mengenai faktor-faktor yang mendasari kebijakan tersebut, untuk membuat penafsiran progresif terhadap makna, substansi, arah dan tujuan dari inovasi Diklat Pim Pola Baru baik dalam perspektif inovasi kebijakan sektor publik maupun dalam perspektif inovasi pembelajaran konstruktivistik.

Berdasarkan uraian yang telah dipaparkan pada bagian latar belakang, maka permasalahan dalam penelitian ini dapat dirumuskan sebagai berikut:

1. Apakah perbedaan Diklat Pim Pola Lama dengan Diklat Pim Pola Baru?

2. Apakah makna strategis dari Diklat Pim Pola Baru bagi upaya menciptakan kompetensi kepemimpinan melalui Diklat Pim?

3. Apakah hambatan implementasi Diklat Pim pola Baru? 


\section{METODE PENELITIAN}

Penelitian ini merupakan suatu studi kepustakaan (library research) yaitu penelitian yang mengkaji berbagai karya tulis ilmiah para peneliti terdahulu, terutama kajian terhadap fenomena aktual dalam berbagai perspektif berdasarkan teori-teori yang relevan. Melalui karya tulis ilmiah berbagai peneliti dan pendapat pakar yang dijadikan sebagai sumber bahan kajian, dapat diperoleh interpretasi atau penafsiran peskriptif yang dibutuhkan untuk merumuskan konsepsi mengenai fenomena aktual yang diteliti.

Penelitian ini mengkaji tentang Diklat Pim Pola Baru sebagai fenomena inovasi kebijakan sektor publik dan sekaligus sebagai inovasi metode pembelajaran Diklat Pim. Alat uji yang digunakan dalam studi kepustakaan adalah semua dokumen-dokumen, buku-buku dan/atau karya tulis ilmiah berupa jurnal atau laporan hasil penelitian yang berkaitan dengan fenomena yang diteliti. Penelitian ini menggunakan pendekatan kualitatif dengan teknik analisis komparatif yang membandingkan Diklat Pim Pola Lama dengan Diklat Pim Pola Baru. Interpretasi hasil komparasi akan menghasilkan dua kemungkinan yaitu: (i) Pola atau konsepsi Diklat Pim Pola Baru sama dengan pola atau konsepsi Diklat Pim Lama; atau (ii) Pola atau konsepsi Diklat Pim Pola Baru tidak sama dengan pola atau konsepsi Diklat Pim Pola Lama.

\section{HASIL PENELITIAN}

\section{Analisis Perbandingan Diklat Pim Pola Lama dan Diklat Pim Pola Baru}

Diklat Pim Pola Baru dalam perspektif kebijakan LAN RI, dapat dipandang sebagai respon adaptif terhadap: (i) tekanan internal bahwa birokrasi di Indonesia tidak efektif karena terjadi kolusi di antara elite birokrasi dan elite partai politik (Ery Riyana Hardjapamekas, 2003), kompetensi dan integritas ASN yang rendah (Men.PAN RB, 2012) dan Diklat Pim Pola Lama sebagai sarana untuk menciptakan pemimpin/elite birokrasi yang berintegritas ternyata tidak efektif (Lilin Budiati, 2012); (ii) tekanan eksternal berupa globalisasi yang mengharuskan bangsa Indonesia mempersiapkan diri menghadapi kompetisi terbuka di pasar bebas pada tahun 2015 (LAN RI, 2013). Tekanan-tekanan tersebut disikapi oleh LAN RI dengan menerapkan pembelajaran Diklat Pim Pola Baru yang selain berorientasi pada kompetensi kepemimpinan, praktik pembelajarannya terpusat pada peserta (student centered)serta difokuskan pada pemahaman nilai, metode dan inovasi yang diperoleh dari pengalaman peserta pada saat merancang dan menjalankan proyek perubahan. Integritas dan karakteristik kepemimpinan juga menjadi unsur pokok yang dinilai dalam Diklat Pim Pola Baru. Terdapat perbedaan substansial antara model pendekatan Diklat Pim Pola Lama dengan model pendekatan Diklat Pim Pola Baru. Model pembinaan, pengendalian dan pengawasan Diklat Pim Pola Lama adalah "pendekatan terpusat (state centered)", di mana semua aktivitas pembinaan, pengendalian dan pengawasan dilakukan oleh negara secara terpusat melalui LAN RI.

Model pendekatan semacam ini hanya memberikan ruang kepada negara sebagai satu-satunya pelaku pembinaan, pengendalian dan pengawasan, dan pada saat yang sama mengabaikan kepentingan para pihak yang terlibat di dalam penyelenggaraan Diklat Pim seperti: Badan Diklat Provinsi dan/atau Badan Diklat Kabupaten/Kota, Pemerintah Daerah dan/atau SKPD tempat asal peserta, pimpinan/atasan peserta, peserta dan masyarakat. Sebaliknya pada Diklat Pim Pola Baru, model pendekatan yang dipakai adalah model intermestik yaitu gabungan beberapa model pendekatan antara lain: (i) model pendekatan domestik (model state centered dan model pluralistik); dan (ii) model internasional; dan (iii) transnasional (Dyah Estu Kurniawati, 2013). Pada model pendekatan intermestik, negara tetap melakukan pembinaan, 
pengendalian dan pengawasan tetapi dalam lingkup dan skala terbatas, dan pada saat yang sama mengakomodasikan berbagai kepentingan para stakeholder yang terlibat, bersifat responsif dan adaptif terhadap berbagai perubahan kebutuhan, tekanan dan tantangan yang dihadapi pemimpin masa depan di era globalisasi. Indikasi bahwa LAN RI hanya melakukan pembinaan, pengendalian dan pengawasan terbatas terhadap implementasi Diklat Pim Pola Baru, terlihat dari kenyataan yang ada bahwa LAN RI hanya menentukan pokok-pokok atau garis besar penyelenggaraan Diklat Pim Pola Baru dalam Perkalan No. 10, No. 11, No. 12 dan No. 13 tahun 2013 tentang penyelenggaraan Diklat Pim Tingkat I, II, III dan IV. Tidak ada petunjuk pelaksanaan (JUKLAK), petunjuk teknis (JUKNIS) atau modul/materi Diklat.

Hal ini harus dimaknai sebagai bagian substantif dari kebijakan Diklat Pim Pola Baru, dimana pemangku kepentingan seperti Badan Diklat Povinsi dan Badan Diklat Kabupaten Kota selaku penyelenggara Diklat Pim justru diberi kesempatan untuk merancang dan merumuskan sendiri JUKLAK, JUKNIS dan modul diklat yang sesuai dengan kondisi, karakteristik dan muatan lokal masing-masing daerah. Terkait dengan aspek inovasi, LAN RI sudah menyadari bahwa pada kebijakan Diklat Pim Pola Lama, Badan Dikat Propinsi dan/atau Badan Diklat Kabupaten/Kota diperlakukan hanya sebagai implementor kebijakan. Hubungan yang ada adalah hubungan berdasarkan otoritas atau kewenangan (hubungan otoritatif). Hubungan otoritatif selalu berimplikasi pada matinya unsur-unsur kreatifitas dan inovasi.

Kondisi tersebut diperbaiki pada kebijakan Diklat Pim Pola Baru, dengan memperlakukan Badan Diklat Provinsi dan/atau Badan Diklat Kabupaten/Kota tidak lagi hanya sebagai implementor kebijakan, tetapi sekaligus mitra kerja bersama-sama dengan pemerintah daerah, organisasi profesi seperti IWI dan masyarakat. Apabila dielaborasi lebih jauh, prinsip-prinsip strategis yang diterapkan oleh LAN RI dalam mewujudkan implementasi Diklat Pim Pola Baru adalah inovasi, partisipasi dan kolaborasi. Badan Diklat Provinsi dan/atau Badan Diklat Kabupaten/Kota diberikan ruang untuk berinovasi, berpartisipasi dan berkolaborasi secara intra dan inter organisasi dengan para stakeholder terkait, termasuk dengan LAN RI dalam mengimplementasikan kebijakan Diklat Pim Pola Baru.

\section{Diklat Pim Pola Baru Dalam Perspektif Inovasi}

Diklat Pim Pola Baru menunjukkan adanya unsur kebaruan (novelty) yang memenuhi syarat sebagai suatu inovasi, sebagaimana yang dikatakan oleh Everett M. Rogers (1983) bahwa inovasi adalah: "an idea, practice, or object perceived as new by the individual or another unit of adoption" atau suatu ide, atau objek yang dianggap/dirasa sebagai sesuatu yang baru oleh seseorang, kelompok atau masyarakat". Definisi Rogers tersebut terlalu sederhana dan bisa menyesatkan, karena hanya menggunakan parameter "kebaruan (novelty)" untuk menentukan apakah sesuatu itu termasuk inovasi atau bukan. Berdasarkan pada berbagai pendapat para ahli maka dapat dirangkum definisi inovasi sebagai berikut:

"Inovasi adalah suatu perubahan baru menuju kearah perbaikan, yang sifatnya lain atau berbeda dari yang sudah ada sebelumnya, spesifik dan unik, yang direncanakan dengan sengaja secara sitematis berdasarkan konsep berbasis pengetahuan dan/atau teknologi".

Inovasi dijalankan secara terencana dan sistematis untuk mencapai hasil yang lebih besar (greater outcome), manfaat yang lebih besar (greater benefit), pengaruh yang lebih besar (greater impact), biaya yang lebih murah (cost effective), risiko yang lebih kecil (lesser risk), sumber daya yang lebih kecil (lesser resources) dan kinerja yang lebih baik (greater performance). Agar tujuan inovasi dapat dicapai, maka inovasi dijalankan berlandaskan prinsipprinsip dasar sebagai berikut: 
1) Diferensiasi Tugas Pokok dan Fungsi (Tupoksi)

2) Penerapan ilmu pengetahuan dan teknologi (IPTEK)

3) Pertumbuhan dan Perkembangan

Kebaruan yang terdapat pada Diklat Pim Pola Baru apabila dibandingkan dengan Diklat Pim Pola Lama dapat dilihat pada tabel 1 antara lain sebagai berikut:

\section{TABEL 1. UNSUR-UNSUR KEBARUAN DIKLAT PIM POLA BARU DIBANDINGKAN DENGAN DIKLAT PIM POLA LAMA}

\begin{tabular}{|c|c|c|}
\hline Dimensi & Diklat Pim Pola Lama & Diklat Pim pola Baru \\
\hline Kebijakan & $\begin{array}{c}\text { Berorientasi pada output berupa } \\
\text { kompetensi peserta, }\end{array}$ & $\begin{array}{c}\text { Berorientasi pada outcome, integritas, } \\
\text { inovasi dan kolaborasi dalam jejaring } \\
\text { kerja }\end{array}$ \\
\hline Paradigma & Administrasi & Pelayanan Publik \\
\hline Penyelenggaraan & $\begin{array}{c}\text { Terpusat pada LAN RI (state } \\
\text { centered) atau model pendekatan } \\
\text { domestik }\end{array}$ & $\begin{array}{c}\text { Kombinasi state centered, pluralistik } \\
\text { dan transnasional (intermestik) }\end{array}$ \\
\hline Pembelajaran & $\begin{array}{c}\text { Behavioristik, Kognitivistik, } \\
\text { competence based learning }\end{array}$ & Ada Diklat off campus \\
\hline Proyek Perubahan & Tidak ada & Ada \\
\hline Coach \& Mentor & Tidak ada & Ada \\
\hline Output Kelulusan & 100\% lulus & Tidak 100\% lulus \\
\hline Konsep Jejaring Kerja & Tidak ada & Ada \\
\hline $\begin{array}{c}\text { Intensitas Kolaborasi } \\
\text { antar lembaga }\end{array}$ & Rendah & Tinggi \\
\hline
\end{tabular}

Diklat Pim Pola Baru termasuk dalam tipe inovasi pengembangan dan perluasan, karena Diklat Pim Pola Baru masih menggunakan unsur-unsur yang terdapat di dalam Diklat Pim Pola Lama tetapi disertai pembaruan terutama di sektor kurikulum, proses penyelenggaraan dan metode pembelajaran Diklat Pim. Sebagai contoh adalah perbandingan antara agenda pertama kurikulum Diklat Pim Pola Lama dengan agenda pertama Diklat Pim pola Baru.Agenda pertama kurikulum Diklat Pim Pola Lama adalah Integritas dan Etika dengan mata diklat: (i) Kepemimpinan Aparatur Pemerintahan; dan (ii) Sistem Administrasi Negara Kesatuan Republik Indonesia. Terdapat inkonsistensi antara agenda kurikulum dengan mata diklat terkait.

Agenda kurikulum yang sudah bersifat spesifik dan sempit (Integritas dan Etika) diberi mata diklat yang bersifat umum dan luas (Kepemimpinan dan Sistem administrasi), sehingga substansi dan esensi mata diklat menjadi tidak jelas atau kabur. Pada Diklat Pim Pola Baru, inkonsistensi di sektor input ini justru diperbaiki. Agenda pertama kurikulum Diklat Pim Pola Baru adalah "Self Mastery" dengan mata diklat: (i) Wawasan Kebangsaan; (ii) Integritas; (iii) Pembekalan isu strategis; (iv) Diagnostic Reading; dan (v) Penjelasan proyek perubahan. Pada Diklatpim Pola Baru, agenda kurikulum konsisten dengan mata diklat terkait. Implementasi Diklat Pim Pola Baru sangat tergantung pada kinerja widyaiswara yang diukur dari kompetensi, integritas, karakter dan perilakunya. Peran dan fungsi strategis widyaiswara selaku implementor di garis terdepan (frontliner) berpengaruh signifikan yang secara langsung menentukan keberhasilan implementasi kebijakan. Peran Badan Diklat Provinsi dan/atau Badan Diklat Kabupaten/ Kota beserta para widyaiswara adalah sebagai agen perubahan (change 
agent). Peran widyaiswara justru yang terpenting karena fungsi yang disandangnya sebagai pendidik, promotor perubahan dan sekaligus coach proyek perubahan.

Ditinjau dari perspektif teori inovasi Rogers (1983), semua widyaiswara adalah adopter Diklat Pim Pola Baru karena terikat oleh kewajibannya sebagai ASN. Tetapi tingkat adopsi di antara mereka tidak sama dan mengikuti pola sebaran frekuensi adopter sebagaimana yang diilustrasikan dalam kurva Rogers (lihat gambar 1). Sebaran persentase adopter di dalam populasi digambarkan oleh Rogers sebagai kurva yang menyerupai genta sebagai berikut:

GAMBAR 1. KURVA SEBARAN PERSENTASE ADOPTER

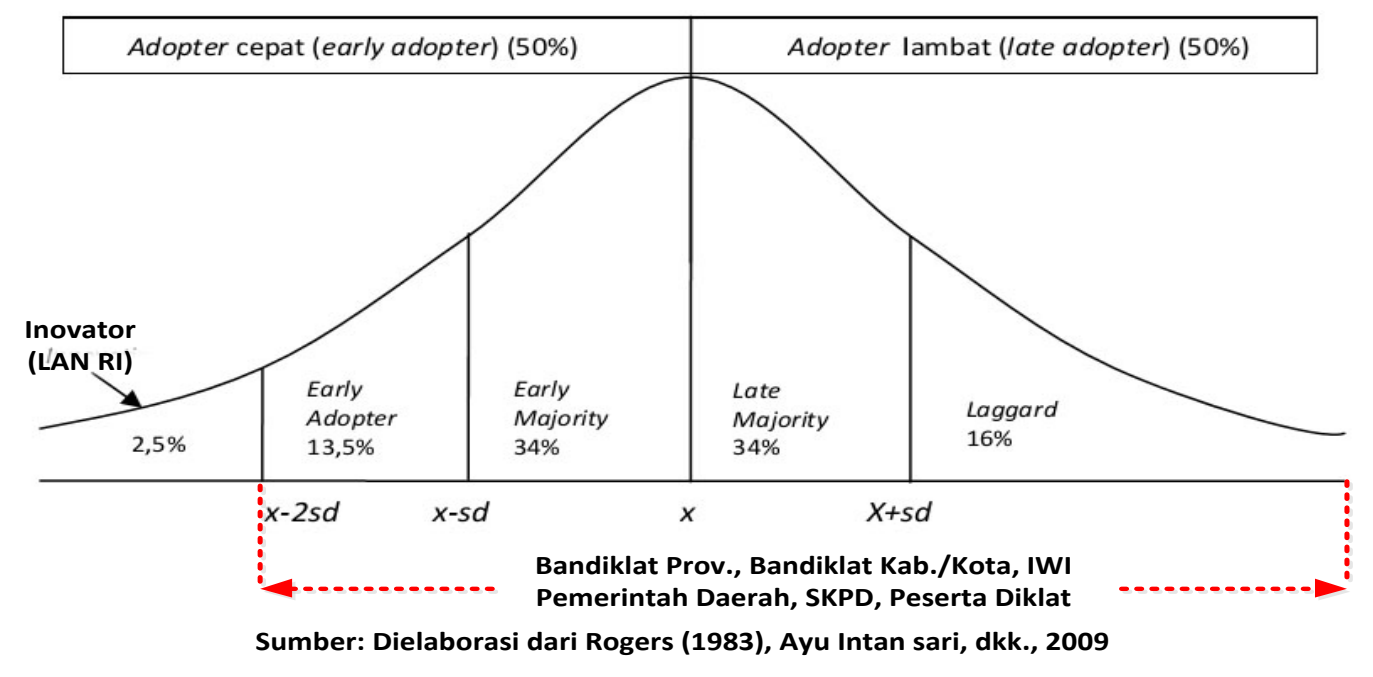

Pada populasi widyaiswara di semua Badan Diklat di Indonesia, selalu terdapat $16 \%$ kelompok adopter konservatif/kolot (laggard). Hambatan terbesar implementasi Diklat Pim Pola Baru terutama bersumber dari resistensi kelompok adopter konservatif/kolot (laggard) ini. Mereka adalah orang-orang yang berpandangan skeptis terhadap setiap perubahan baru atau inovasi yang selalu menimbulkan ketidakpastian yang memaksa mereka harus mempelajari hal-hal baru yang terkandung di dalam inovasi. Kelompok ini mempertahankan kondisi status quo yang telah memberikan kemapanan dan rasa aman terhadap dirinya, sehingga mereka resisten dan bahkan apabila situasinya memungkinkan menolak perubahan. Dalam Diklat Pim Pola Baru, terdapat sejumlah mata diklat baru antara lain wawasan kebangsaan, integritas, diagnostic reading, benchmarking dan proyek perubahan yang memaksa mereka harus belajar lagi agar dapat menjalankan tugasnya dengan benar dan baik. Kondisi ini dirasakan sangat menyulitkan bagi kelompok laggard, khususnya mereka yang sudah sangat senior di dalam jajaran birokrasi dan sudah merasa mapan dalam perangkap konservatisme. Implikasi dari kondisi ini adalah munculnya gejala pragmatisme dalam implementasi Diklat Pim Pola Baru. Praktik pembelajaran tidak didasarkan pada aspek substansi tugas pokok dan fungsi widyaiswara, melainkan didasarkan pada segi praktis dari pelaksanaan tugas dan fungsi tersebut.

Gejala perilaku yang mungkin timbul pada situasi ini antara lain: (i) Pembenaran diri (self justification) berdasarkan senioritas; widyaiswara membuat penafsiran subjektif terhadap materi mata diklat dan berharap diikuti oleh para yunior di sekitarnya meskipun substansinya tidak jelas serta tidak ada referensi ilmiah pendukung; (ii) Reduksi dan simplifikasi; substansi mata diklat direduksi dan disederhanakan sehingga materi diklat menjadi kabur dan kehilangan makna; (ii) Mengutamakan segi praktis dan mengabaikan teori dan konsep; pembelajaran 
dilaksanakan berdasarkan kebiasaan yang bersifat praktis, teori dan konsep direduksi sampai tidak dapat dilacak validitas sumbernya, karena sebagian besar merupakan pendapat subyektif. Apabila ada peserta yang berkonsultasi menanyakan substansi materi diklat yang tidak jelas, peserta disuruh mencarinya sendiri di buku-buku atau internet. Dengan demikian, dapat disimpulkan bahwa tingkat adopsi kelompok adopter konservatif (laggard) adalah adopsi simbolis saja, karena bentuk adopsinya hanya sekedar tampak melaksanakan saja tetapi tidak didukung dengan isi dan perilakunya dalam praktik pembelajaran.

Alasan paling rasional atas terjadinya fenomena pragmatisme di atas adalah bahwa para widyaiswara yang tergolong dalam kelompok adopter lambat (late majority) dan khususnya kelompok adopter konservatif (laggard) tidak memahami substansi materi diklat, tetapi enggan dan malas untuk berupaya mencari informasi dan belajar lagi tentang materi baru tersebut karena dirasakan sangat merepotkan. Belajar dirasakan sebagai hal yang menyusahkan karena harus mengerahkan kemampuan pikiran, tenaga dan sumber daya ekstra padahal mereka sudah nyaman dengan keadaan sebelumnya.

Implikasi praktis yang mungkin timbul dari kondisi ini antara lain adalah: (i) peserta tidak diberi pembekalan yang cukup tentang substansi materi diagnostic reading, inovasi, manajemen proyek dan benchmarkng ke best practice sebelum merancang proyek perubahan, karena widyaiswara sendiri tidak memahaminya; (ii) widyaiswara tidak bisa memberikan coaching yang optimal dalam perancangan dan pelaksanaan proyek perubahan karena mereka tidak memahami tentang substansi dan manajemen suatu proyek; (ii) widyaiswara/penguji tidak memahami indikator, instrumen pengukur, satuan ukur dan kriteria penilaian karena mereka tidak memahaminya, sehingga penilaian pada saat ujian tidak valid, artinya tidak menilai apa yang seharusnya dinilai. Penilaian lebih ditentukan oleh subjektifitas penguji/narasumber. Ironisnya, penguji/narasumber justru tidak memahami tentang apa yang diujinya.

\section{Diklat Pim Pola Baru Dalam Perspektif Pembelajaran Konstruktivistik}

Konstruktivisme adalah pandangan filsafat yang dikemukan oleh Giambatista Vico (1710) yang pada prinsipnya mempunyai pengertian bahwa "seseorang dapat memahami suatu pengetahuan tertentu apabila ia sudah membangun atau mengkonstruksikan sesuatu, sehingga ia dapat menjelaskan tentang unsur-unsur apa yang telah dikonstruksi" (Suparno, 1997 dalam Sutarjo Adisusilo, 2009). Filsafat konstruktivisme beranggapan bahwa pengetahuan adalah hasil konstruksi mental manusia terhadap segala hal yang direfleksikan oleh pengalamanya melalui interaksi dengan subjek, objek dan fenomena yang terdapat di lingkungan sekitarnya. Konstruktivisme adalah salah satu pandangan dan sekaligus teori pembelajaran yang menyatakan bahwa dalam proses belajar (perolehan pengetahuan) diawali dengan terjadinya konflik kognitif yang hanya dapat diatasi melalui pengetahuan diri dan pada akhir proses belajar pengetahuan akan dikonstruksikan oleh peserta didik melalui pengalamannya sebagai hasil interkasi dengan lingkungannya (Karli, 2003).

Proses pembelajaran yang didasarkan pada pengalaman peserta didik dalam mengkonstruksikan objek belajar, sedemikian sehingga peserta didik dapat mengkonstruksikan struktur mental yang terdiri dari dari pengetahuan, konsep yang tersimpan di dalam memori yang sewaktu-waktu dapat direpresentasikan, diekspresikan dan ditransfer pada situasi baru, disebut sebagai "Pembelajaran Konstruktivistik" atau "Pembelajaran berbasis pengalaman (experience based learning)" (Peggy A. Ertmer dan Timothy J. Newby, 2013). 
Menurut Peggy A. Ertmer and Timothy J. Newby, (2013), pendekatan konstruktivistik sangat tepat digunakan pada proses pembelajaran yang bertujuan untuk mencapai tingkat kompetensi yang canggih (sophisticated) dan kinerja tinggi (high performance). Dua hal itu yang sangat dibutuhkan untuk menghadapi tantangan kompetisi yang sangat ketat di pasar bebas pada tahun 2015, sehingga kebijakan LAN RI yang menetapkan "proyek perubahan" sebagai alat pembelajaran konstruktivistik di dalam Diklat Pim Pola Baru sudah sesuai dengan filafat, teori, paradigma, praksis dan strategi pendidikan konstruktivistik yang dikemukakan oleh Vygotsky, John Dewey, Vico Rorty dan Bruner Jonassen.

Menurut Keith S. Taber (2011), konstruktivisme merupakan paradigma/pendekatan dan sekaligus teori pendidikan. Sementara Peggy A. Ertmer and Timothy J. Newby, (2013) menambahkan bahwa konstruktivisme juga merupakan "strategi pendidikan" untuk menghasilkan tingkat kompetensi canggih (sophisticated) dan kinerja tinggi (high performance) dari peserta didik. Dengan demikian, Diklat Pim Pola Baru dapat dikatakan sebagai pendekatan, teori dan sekaligus strategi pembelajaran konstruktivistik.

Sebagai suatu strategi, pembelajaran konstruktivistik lebih unggul dibanding pembelajaran behavioristik dan pembelajaran kognitivistk sebagaimana yang terlihat pada gambar 2 berikut ini:

\section{GAMBAR 2. PERBANDINGAN STRATEGI PEMBELAJARAN BEHAVIORISTIK, KOGNITIVISTIK DAN KONSTUKTIVISTIK}

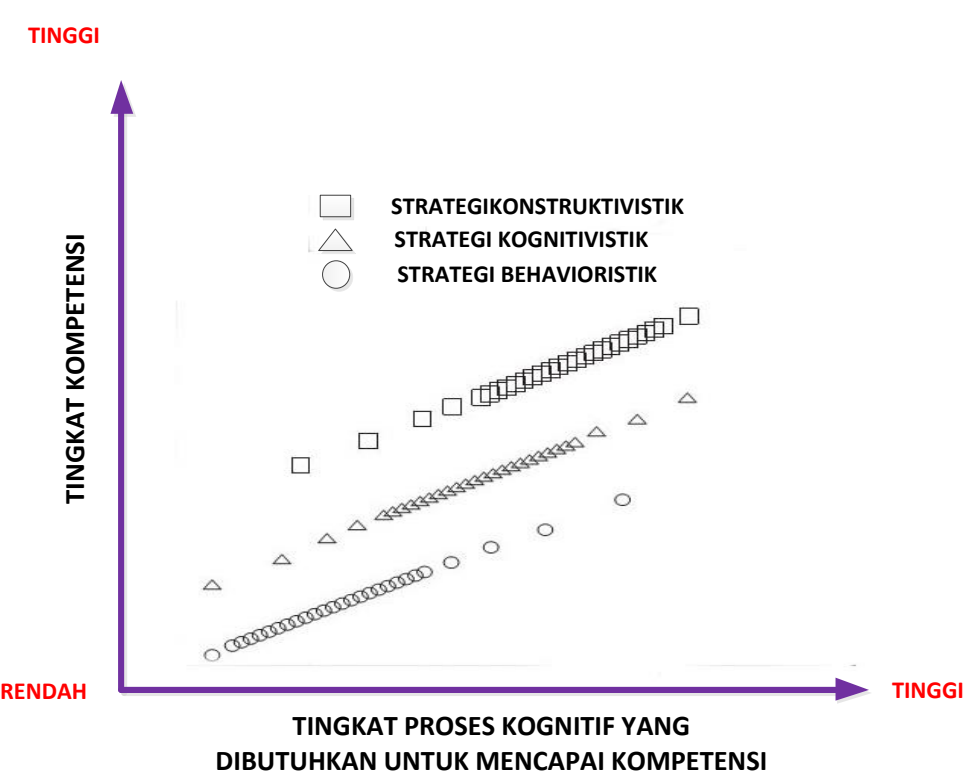

Sumber: Peggy A. Ertmer and Timothy J. Newby, 2013

Pada gambar 2 ditunjukkan bahwa tingkat kompetensi yang tinggi membutuhkan tingkat proses kognitif yang tinggi pula, dan srategi pembelajaran yang paling tepat untuk diterapkan adalah "Strategi Pembelajaran Konstruktivistik". 


\section{KESIMPULAN}

1. Perbedaan substansial antara Diklat Pim Pola Lama dengan Diklat Pim Pola Baru adalah pada faktor inovasinya yang mencakup dua aspek yaitu: (i) inovasi kebijakan berupa penetapan "proyek perubahan" sebagai objek pembelajaran Diklat Pim Pola Baru; (ii) inovasi pembelajaran berupa penerapan penerapan pendekatan dan/atau teori pembelajaran konstruktivistik berbasis pengalaman dalam merancang dan melaksanakan proyek perubahan sebagai strategi pembelajaran.

2. Makna strategis Diklat Pim Pola Baru ditujukan untuk menciptakan pemimpin birokrasi yang memiliki kompetensi kepemimpinan adaptif, yang mampu mendorong dan menggerakkan orang lain di dalam organisasi dan organisasinya agar selalu mampu beradaptasi terhadap perubahan dengan cara berinovasi secara terus menerus dan berkolaborasi membentuk jejaring kerja

3. Hambatan implementasi Diklat Pim Pola Baru adalah tingkat difusi dan adopsi inovasi yang rendah dari widyaiswara, karena tingkat kesulitan yang tinggi dan ketidaksesuaian inovasi dengan kompetensi riil widyaiswara yang tidak memiliki kompetensi manajemen proyek. Hambatan lain adalah adopsi simbolis, reduksi/penyederhanaan pengertian, substansi dan penilaian dari proyek perubahan.

\section{REKOMENDASI}

1. Bagi LAN RI

a. Membuat kebijakan tentang pelatihan widyaiswara agar memiliki kompetensi manajemen proyek sehingga mampu mengajar, melatih dan membimbing peserta dalam merancang dan melaksanakan proyek perubahan

b. Membuat kebijakan untuk menetapkan Badan Diklat Provinsi dan/atau Badan Diklat Kabupaten/Kota untuk merumuskan indikator-indikator pelaksanaan perancangan, pelaksanaan dan penilaian proyek perubahan yang memenuhi syarat-syarat validitas dan reliabilitas variabel kepemimpinan adaptif sebagaimana yang dijelaskan pada tabel 5 halaman 33.

c. Menghapuskan pembatasan yang melarang peserta Diklat Pim bertemu secara tatap muka dengan widyaiswara selaku pelatih dan pembimbing dalam merancang dan melaksanakan proyek perubahan.

d. LAN RI membuat kebijakan yang menetapkan bahwa:

1) Peserta Diklat Pim harus melakukan studi kelayakan proyek terlebih dullu sebelum mengusulkan proposal proyek perubahan.

2) Proposal proyek perubahan harus sudah diajukan sebelum mengikuti Diklat Pim.

2. Bagi Badan Diklat Provinsi dan/atau Badan Diklat Kabupaten/Kota

a. Kebijakan Diklat Pim Pola Baru secara implisit dapat ditafsirkan sebagai peluang bahwa LAN RI menyerahkan penyusunan modul, indikator, instrumen dan kriteria penilaian, JUKLAK, JUKNIS untuk implementasi Diklat Pim Pola Baru.

b. Badan Diklat Provinsi dan/atau Badan Diklat Kabupaten Kota harus membuat model implementasi Diklat Pim Pola baru setelah sebelumnya melakukan riset empris lebih dulu.

c. Badan Diklat Provinsi dan/atau Badan Diklat Kabupaten/Kota mengadakan diskusi panel, seminar, workshop dan pelatihan untuk menyamakan persepsi tentang Diklat Pim Pola Baru, khususnya "proyek perubahan" guna meningkatkan kompetensi widyaiswara tentang manajemen proyek 
d. Badan Diklat Provinsi dan/atau Badan Diklat Kabupaten/Kota bekerjasama dengan Perguruan Tinggi, Lembaga Riset, organisasi profesi widyaiswara dalam melaksanakan kegiatan pada huruf $\mathrm{c}$ di atas.

\section{KETERBATASAN PENELITIAN}

Penelitian ini adalah studi kepustakaan (library research) yang hanya mengkaji dan membandingkan teori, konsep dan pendapat para pakar melalui buku-buku teks (textbook), jurnal, artikel atau makalah dari berbagai sumber yang tersedia, mengenai Diklat Pim pola Baru baik sebagai inovasi kebijakan maupun sebagai inovasi pendekatan, teori dan strategi pembelajaran konstruktivistik. Dengan demikian, studi ini memiliki keterbatasan bahwa pemikiran, asumsi dan simpulan yang diperoleh peneliti masih bersifat hipotetis dan masih harus dibuktikan kebenarannya melalui suatu riset empiris tentang implementasi Diklat Pim Pola Baru. Hal itu sangat diperlukan guna memperoleh solusi terhadap masalah-masalah yang timbul dan sekaligus menemukan model implementasi Diklat Pim Pola Baru.

\section{AGENDA PENELITIAN MENDATANG}

Berdasarkan keterbatasan yang terkandung dalam studi kepustakaan, maka harus diagendakan suatu riset empiris tentang implementasi Diklat Pim Pola Baru, untuk membuktikan kebenaran asumsi-asumsi hipotetis yang diperoleh melalui penelitian ini.

\section{DAFTAR PUSTAKA}

Halvorsen Thomas, Hauknes Johan, Miles Ian and Røste Rannveig, Innovation In Public Sector: On the differences between public and private sector innovation, PUBLIN REPORT No. D9, Oslo, 2005

Lekhi Rohit, Public Service Innovation: A Research Report for The Work Foundation's Knowledge Economy Programme, Research Republic LLP, Manchester, 2007

Matthews Mark, Lewis Chris, Cook Grahame, Innovation in the Public Sector: Enabling Better Performance, Driving New Directions, ANAO Report, Australia National University, 2009

Rogers M. Everett, Diffusion of Innovation, 4th Edition, Free Press, New York, 1983

R.G. Havelock,. The Change Agent's Guide to Innovation in Education. New Jersey: Englewoods Cliff, 1978

Skogen, Kjell. 1997. An Introduction to the Process of Innovation. Chapter II in DSSI-project. Socrates Programme 25234-CP-1-96-NO-ODL (http://www.uoc. .es/dssi/)

Peggy A. Ertmer and Timothy J. Newby, Behaviorism, Cognitivism, Constructivism: Comparing Critical Features From an Instructional Design Perspective, Wiley, 2013

Taber. S. Keith, Constructivism as Educational Theory: Contingenciy in Learning and Optimally Guided Instructions, Science Publisher Inc., ISBN 978-1-61324-580-4, 2011

Applefield. M. James, Huber Richard \& Moallem Mahnaz, Constructivism In Theory And Practice: Toward A Better Understanding, Univesity if North Carolina, Wilmington 2003 
Vygotsky, L.S., Mind in society: The development of higher psychological processes. (M. Cole, V. John-Steiner, S. Scribner \& E. Souberman, Eds. and Trans.). Cambridge, MA: Harvard University Press, 1978

Cooper, P.A. Paradigm shifts in designed instruction: From behaviorism to cognitivism to constructivism. Educational Technology, 33:12-19, 1993.

Sterling Stephen, Transformative Learning and Sustainability: sketching the conceptual ground, University of Plymouth, Learning and Teaching in Higher Education, Issue 5, 2010-11

Kolb, D., Experiential learning. Englewood Cliffs, NJ: Prentice Hall, 1984.

Askew, S. and E. Carnell, Transforming Learning: individual and global change. London: Cassell, 1998.

Joyce, B.; Weil, M.; Showers, B Models of Teaching (4th Ed). Boston: Allyn and Bacon, 1992. 